\title{
Transnistrien næste brændpunkt?
}

Af Ruxandra Lupu Dinesen

Annekteringen af Krim i marts 2014 har bragt vestlig medieopmærksomhed til de mange fastlåste konflikter, der kom til som følge af Sovjetunionens kollaps. Der har været spekulationer, om Putin også kunne finde på at annektere Abkhasien og Sydossetien (i Georgien) og Transnistrien (i Moldova) som reaktion på de associeringsaftaler, som blev underskrevet i juni 2014 mellem EU, Georgien og Moldova. De er alle de facto uafhængige stater, men ikke anerkendt internationalt, og de bliver alle støttet økonomisk og militært af Rusland.

Moldova er en meget interessant case på grund af placeringen mellem et EU-land, Rumænien, på den ene side og Ukraine på den anden samt tilstedeværelsen af Transnistrien-konflikten, som i modsætning til andre fastfrosne konflikter ikke handler i så høj grad om etnicitet, men har en mere økonomisk og politisk karakterer.

Moldovas sikkerhed, stabilitet og økonomiske udvikling er sammenflettet med nabolandenes og derfor kan et potentielt sammenbrud af den ukrainske stat eller en forlænget væbnet konflikt i det østlige og sydlige Ukraine skade Moldova på mange måder.

Økonomisk er Ukraine Moldovas tred- jestørste handelspartner med 15,6 pct. af den samlede udenrigshandel i 2012. Landet fungerer også som en vigtig transitrute for moldoviske varer til betydelige markeder i Hviderusland og Rusland samt for vandrende arbejdstagere.

Mere end 300.000 moldovere arbejder i Rusland, enten midlertidigt eller permanent, og de fleste krydser Ukraine med bus eller tog på vejen til Rusland.

Endvidere modtager Moldova størstedelen af sin gas fra Rusland via ukrainsk territorium. Hvis Gazprom skulle finde på at afbryde strømmen af gas til Ukraine, ville Moldova også blive afskåret. Sidst, men ikke mindst, importerer Moldova 40 pct. af al elektriciteten (i 2013) fra Ukraine. Hvis det ukrainske selskab ikke ville være i stand til at levere elektricitet, ville Moldovas afhængighed af Cuciurgan kraftværk, som befinder sig i Transnistrien, og som ejes af det russiske energiselskab Inter RAO UES, stige. Derfor vil forlængelse eller forværring af konflikten i Ukraine have en negativ indvirkning på den moldoviske økonomi.

Af endnu større betydning er hensynet til Moldovas sikkerhed. Takket være Ukraine deler Moldova ikke grænse med Rusland. Det har - indtil videre begrænset Ruslands militære muligheder i løsningen af striden om Transnistri-

Ruxandra Lupu Dinesen er forsker i Østeuropa og EU's udenrigspolitik på Københavns Universitet. 
en og især forhindret uautoriserede nye forsyninger af de ca. 1500 russiske tropper, der stadig er baseret i Transnistrien. Det har også været en faktor i Ruslands tilbageholdenhed i at annektere Transnistrien. Desuden har Ukraine ofte spillet en konstruktiv rolle og handlet for at nedtrappe spændinger i regionen.

\section{Europas sorte plet}

Transnistrien har været en sort plet på Europas kort i næsten to årtier. Fra 1940 til 1991 var Transnistrien en del af den Moldoviske Socialistiske Sovjetrepublik. I november 1989 vedtog det moldoviske parlament loven om at gøre moldovisk til det officielle sprog samt at indføre det latinske alfabet. Dette skabte frygt blandt den russisktalende befolkning i Transnistrien, hvis befolkning består af nogenlunde lige dele af moldovere, krainere og russere, for at landet ville genforenes med Rumænien, som den moldovisk-talende del af befolkningen har stærke kulturelle og sproglige bånd med, og derfor gjorde de oprør. Interessant nok så vi samme mønster i februar 2014, da den nye regering i Ukraine, dannet efter Maidan-pro-

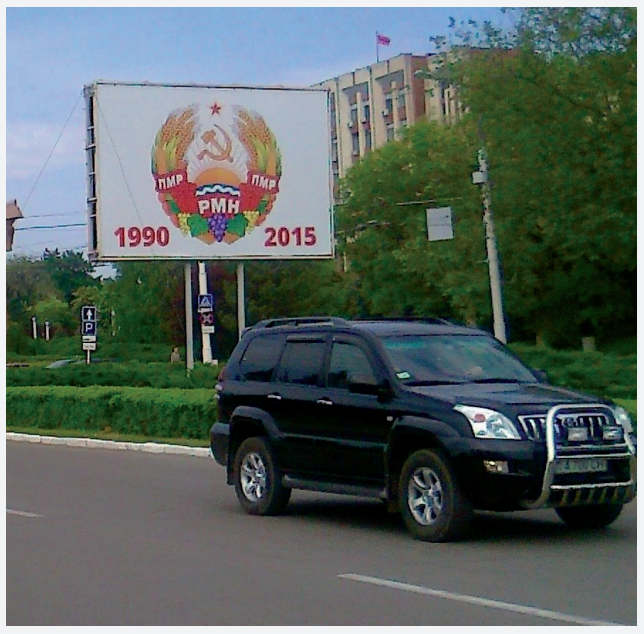

FOTO: Hanne Munk, 2015 testerne i Kiev, gjorde den samme fejl ved at foreslå at afskaffe russisk som et regionalt officielt sprog - et træk der blev set som provokation i den østlige del af landet, og som eskalerede den politiske konflikt og samtidigt gav Putin et påskud for at intervenere.

Efter en kort krig i 1992, afsluttede en russiskmæglet våbenhvile kamphandlingerne i Transnistrien og 'frøs' konflikten. Siden da har der stort set ikke været nogen væbnede kampe. De transnistriske oprørere blev delvist støttet af russiske tropper fra den 14. sovjetiske armé som var udstationeret i Tiraspol, Transnistriens 'hovedstad'.

Selvom de fleste russiske tropper som befandt sig på moldovisk og transnistrisk territorium har forladt landet, er der stadigvæk en russisk militær tilstedeværelse i Transnistrien på omkring 1500 tropper som 'fredsbevarende'. Til trods for at Rusland kan lide at male et rosenrødt billede af Transnistrien, har regionen lidt på grund af dets status. Befolkningen er skrumpet ind fra 750.000 på tidspunktet for de facto adskillelsen til omkring $500.000 \mathrm{i}$ dag, mest af økonomiske årsager.

De transnistriske myndigheder nægter

Transnistriens 'rigsvåben' med den røde stjerne og hammer og segl i midten hænger langs landevejene i Transnistrien og præger ligeledes gadebilledet overalt i hovedstaden Tiraspol. De tre forkortelser står for det officielle navn 'Den Pridnestroviske Moldaviske Republik' på moldovisk, russisk og ukrainsk, og tallene 1990 og 2015 symboliserer 25-året for republikkens uafhængighedserklæring. 
Forhandlinger om en politisk løsning på Transnistrien-konflikten foregår i de såkaldte 5+2-forhandlinger i OSCE-regi (Organisation for Sikkerhed og Samarbejde i Europa]. Moldova og Transnistrien deltager som konfliktens parter, mens OSCE, Rusland og Ukraine fungerer som mæglere. Негudover deltager EU og USA i forhandlingerne som observatører.

at afholde en folketælling af frygt for, at resultatet ville afsløre, at regionen er ved at forvandle sig til en russisk garnison og et alderdomshjem. Ud over den politiske og administrative elite samt den russiske hær er det kun pensionisterne, som har en grund til at blive boende, idet de får betydelig højere pensioner end i resten af Moldova.

De fleste unge læser i Chisinau, Moldovas hovedsted, og de fleste transnistrier har både et russisk og et moldovisk pas, idet de er klar over fordelen ved det moldoviske pas, efter at moldovere fik visumfrihed til EU sidste år.

Selvom der er stærke følelsesmæssige bånd til Rusland, går både den lovlige og den ulovlige eksport primært til Europa. Man hører ofte om Transnistrien som et sted, der forbindes med smugling af våben, tobak, alkohol og sommetider mennesker. Den lovlige eksport som består af stål, cement, tekstiler og elektricitet går hovedsageligt til Moldova (35 pct.), Polen (16 pct.), Italien (9 pct.) og Rusland (13 pct.). Der eksporteres også til Tyskland, Østrig og Grækenland.

Men økonomien er langt fra selvforsynende. Uden de midler, der kommer fra videresalg af russisk gas til forbrugerne, pengeoverførsler fra udenlandske arbejdstagere (som arbejder primært i Rusland) og direkte finansiel støtte fra Rusland, ville staten gå konkurs.

\section{$5+2$ forhandlingerne}

Forhandlinger om en politisk løsning på Transnistrien-konflikten foregår i de såkaldte 5+2-forhandlinger i OSCE-regi (Organisation for Sikkerhed og Samarbej- de i Europa). Moldova og Transnistrien deltager som konfliktens parter, mens OSCE, Rusland og Ukraine fungerer som mæglere. Herudover deltager EU og USA i forhandlingerne som observatører.

Efter flere år med stilstand i konfliktløsningen blev $5+2$ forhandlingerne genoptaget i 2012. Dette skyldes magtskiftet i 2009 i Moldova, hvor det kommunistiske styre blev skiftet ud med en EU-venlig regering, og ikke mindst, at den mere forhandlingsvillige Evgeny Shevchuk i december 2011 afløste Igor Smirnov som Transnistiens 'præsident'.

Siden da er dialogen mellem de to parter intensiveret, og det har bl.a. ført til genetablering af jernbanetrafik samt aftaler om genetablering af telekommunikation. EU har også involveret sig i løsningen af konflikten ved at udstationere en grænsemonitoreringsmission (EUBAM) på grænsen mellem Moldova/ Transnistrien og Ukraine blandt andet med henblik på at begrænse smugleri og organiseret kriminalitet. Dog har hverken forhandlinger i OSCE-regi eller EUBAM ført til en løsning på konflikten endnu.

\section{Fremtiden?}

Men hvad betyder Krims annektering for Transnistriens fremtid? Umiddelbart efter annekteringen sendte den transnistriske parlamentsformand en anmodning til formanden for den russiske Duma, om at Transnistrien officielt skulle blive en del af Rusland. Anmodningen blev afvist. Siden indgåelsen af våbenhvilen i 1992 har Rusland støttet Transnistrien gennem gratis tilførsel af gas og har givet direkte finansiel støtte til Transnistriens budget 
samt forsynet pensionister med et 15 dollar per måned pensionstillæg, uanset statsborgerskab.

Transnistriens beliggenhed er vigtig for Rusland både som base for at holde øje med det uroplagede Balkan-område og som forhindring af en NATO- eller/ og EU-udvidelse til landene i det tidligere Sovjetunionen. Derudover er Rusland bekymret over USA's planer om at udbygge et europæisk missilskjold, som indebærer landbaserede missilbaser, som den nyopstillede base i Deveselu i Rumænien ved Sortehavet, der vil være operationel fra i år (2015) og en base i Polen, der vil være anvendelig fra 2018.

Men Rusland har ingen intention om at indlemme Transnistrien i Rusland eller fortsætte sin økonomiske støtte i samme omfang som hidtil.

Tegn på det sidste kunne ses i starten af januar 2015, da Rusland stoppede med at betale det ekstra pensionstillæg. Dette skyldes, at Ruslands statskasse er ved at tømmes for penge på grund af de vestlige sanktioner, og at Rusland også $ø$ konomisk støtter udbryderrepublikkerne Abkhasien og Sydossetien i Georgien. Drømmescenariet ville være at have Transnistrien som en del af et føderalt Moldova, og på den måde bruge Transnistrien til at kontrollere Moldovas fremtid og forhindre det $i$ at dreje mod Vesten.

En illustration af denne politik er det såkaldte Kozak-memorandum fra 2003 (Dmitri Kozak er Vladimir Putins viceminister for administrative anliggender), som til dags dato er det mest omfattende forslag til en løsning af konflikten. Dette ville have givet Transnistrien de facto vetoret i vigtige beslutninger taget af regeringen i Chisinau og opretholdt russiske tropper i Tiraspol indtil 2020. Efter pres fra USA og EU blev aftalen ikke underskrevet.
Samme scenario ses i Ukraine i forhold til de nye selvudråbte republikker i Donbass-regionen. Moskva ønsker, at disse skal være en del af en føderation med Ukraine. Ruslands udenrigsminister Lavrov har sagt, at Ukraine burde lave en forfatningsreform, som vil give Donbassregionen udstrakt autonomi.På den måde sikrer Putin, at hverken Moldova eller Ukraine optages i EU eller NATO, fordi ingen af de to organisationer ønsker at optage medlemmer med territoriale stridigheder.

Dog er der nogle vigtige forskelle mellem Transnistrien og Donbass-regionen, som gør, at Donetsk og Luhansk ikke kan have samme indflydelse på Ukraines daglige politiske og økonomiske virke.

På den ene side har Donbass ti gange Transnistriens befolkning, fælles grænse med Rusland og officielt ingen russiske soldater. På den anden er Donbass langt mindre politisk og økonomisk vigtig vis-a-vis resten af Ukraine, end Transnistrien er i forhold til Moldova. I modsætning til Transnistrien krydser vigtige gasrørledninger ikke de separatistiske territorier, og på den måde bliver separatisterne frataget et vigtig forhandlingsvåben i forhold til at kunne påvirke og destabilisere Ukraine. Og så ville Ruslands finansielle og militære støtte til det langt større Donbass være betydeligt højere end i Transnistrien. Dette ville gøre Donbass langt sværere for Moskva at håndtere.

Men så længe Vesten ikke agerer mere målrettet i forhold til sine egne interesser, er Moskva tilfreds med den prekære status quo situation i de to regioner.

\section{EU's naboskabspolitik}

Hvad er Moldovas fremtid de ovennævnte udfordringer taget i betragtning? I forbindelse med Ukraine-krisen har EU for første gang vist tydelige tegn på, at man 


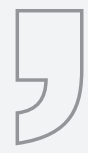

Selvom Rusland altid har betragtet Moldova som en vigtig del af sit nære udland, har EU ikke gjort det før den store øst-udvidelse i 2004, da EU oprettede sin naboskabspolitik omfattende både de tidligere Sovjetlande og de sydlige Middelhavnslande. Igennem en fælles naboskabspolitik ville man sikre sig stabilitet ved sine grænser, samtidigt med, at man var nødt til at finde et alternativ til yderligere udvidelse.

ikke vil acceptere en deling af Moldova, og at man vil gå langt for at holde landet på demokrati-vejen.

Selvom Rusland altid har betragtet Moldova som en vigtig del af sit nære udland, har EU ikke gjort det før den store øst-udvidelse i 2004, da EU oprettede sin naboskabspolitik omfattende både de tidligere Sovjetlande og de sydlige Middelhavnslande. Igennem en fælles naboskabspolitik ville man sikre sig stabilitet ved sine grænser, samtidigt med, at man var nødt til at finde et alternativ til yderligere udvidelse.

EU's politik over for Moldova, Ukraine og Georgien indbefatter en meget langsigtet strategi, som går ud på, at partnerlandene skal indføre meget omfattende reformer inden for områder som demokratiudvikling, menneskerettigheder, retslige anliggender med mere til gengæld for, blandt andet, en større andel i EU's indre marked, visumliberalisering og større økonomisk hjælp.

Moldova har faet en stor strategisk betydning for troværdigheden af EU's politik over for sine naboer og især det seneste Østlige Partnerskabs succes. Først og fremmest er Moldova vigtig for EU på grund af Transnistrien-konflikten, som er den tætteste på EU efter Rumæniens optagelse i EU i 2007. Rumæniens medlemskab af EU har også betydet, at der er omkring 500.000 moldovere, som holder rumænsk og derfor EU-pas. Moldovas stort set rumænsk-talende befolkning har nære bånd med og har været en del af Rumænien mellem de to verdenskrige.

Efter Moldova har skiftet kurs mod
EU, især efter 2009 hvor en EU-venlig regering er kommet til magten, har Rusland vist tænder, som de også har gjort $\mathrm{i}$ forhold til andre tidligere sovjetlande.

For eksempel i oktober 2013, kun en måned før EU-topmødet i Vilnius, indførte Rusland endnu engang embargo for import af moldovisk vin og frugt, således som de gjorde i 2006.

Moldovas øgede betydning for EU kunne ses reaktionen, idet EU denne gang reagerede ved at lette adgangen for moldovisk vin og frugt til EU-markedet, selvom et sådant tiltag først skulle træde i kraft efter underskrivelsen af associeringsaftalen med EU, som blev initieret i Vilnius i november 2013.

Yderligere, efter optrapningen af konflikten i Ukraine, underskrev EU aftalen med Moldova allerede i juni 2014, i modsætning til den oprindelige plan om at gøre det i december 2014. Og i marts 2014 godkendte Europa-Parlamentet, efter et meget hurtigt forhandlingsforløb, aftalen om fri bevægelighed i Europa for bestemte grupper af moldovere. EU har stået fast på princippet om demokratisk konditionalitet og har ydet støtte på de rigtige tidspunkter.

\section{To scenarier for Moldova}

Om det lykkes Moldova at fortsætte i demokratisk retning afhænger i høj grad af, hvad der sker i Ukraine. Hvis Putin mister indflydelse i Ukraine, hvilket intet tyder på, vil han muligvis skrue op for presset på Moldova gennem tiltag som total embargo af moldovisk vin og frugter, afbrydelse af gasforsyning, indrejseforbud for moldoviske arbejdere. 
300.000 til 400.000 moldovere arbejder i dag i Rusland. Men heldigvis er forholdet mellem Moldova og Rusland ikke så anspændt som forholdet mellem Rusland og Ukraine. Moldova har strategisk været meget klogere og opretholdt dialogen med både Moskva, Transnistrien, Ukraine samt EU og USA.

Det er stadigvæk uvist, hvor Moldovas fremtid hører til. Men det er ikke betryggende, at i modsætning til Ruslands trusler, som har rystet moldoverne, forbliver EU's løfter om integration ukonkrete for størstedelen af befolkningen og afhængige af Moldovas gode opførsel. Mens de moldoviske politiske eliter ønsker landet integreret i EU, er befolkningen mere splittet mellem de gamle, som bor på landet, har brændeovn og med nostalgi husker deres liv under Sovjetunionen, og de unge, som bor i byerne, har mobiltelefon og internet og derfor ønsker demokrati og integration i EU.

Der findes to mulige scenarier for Moldova: enten som en forarmet, militariseret russisk koloni eller som modtager af EU-integration og europæiske værdier.

Hvis konflikten i Ukraine skulle eskalere, ville de russiske tropper, som befinder sig $i$ Transnistrien, muliggøre, at Rusland kunne lancere en vestlig offensiv mod Odessa, en værdsat port til Sortehavet og nuværende hjem for den ukrainske flåde. Odessaregionen strækker sig helt ned til Donau og grænser op både til Transnistrien, Moldova, Rumænien og Bulgarien.

Odessa er et af de vigtigste punkter i ideen om Novorossija, Det Nye Rusland noget, der er blevet nævnt siden annekteringen af Krim. Novorossija ville omfatte hele den østlige og sydlige del af Ukraine, fra Krim til Donau og på den måde forbinde Transnistrien direkte med Rusland i det tilfælde, at Putin vil have samme model som for Krim. Eller disse republikker kunne indgå i et totalt føderaliseret Ukraine, dog med stor russisk indflydelse.

Men der er meget, der tyder på, at dette scenario ikke er aktuelt, i hvert fald ikke i øjeblikket. Samtidigt virker Moldova fast besluttet på at bevæge sig mod EU, idet det ser ud som den eneste mulighed for et selvstændigt demokratisk Moldova.

Håbet i EU er, at jo mere Moldova udvikler sig i en demokratisk retning og får økonomisk stabilitet, jo mere attraktivt ville det være for Transnistrien at tilslutte sig Moldova igen i en eller anden form for udstrakt selvstyre. Transnistrien står i en meget vanskelig økonomisk situation i øjeblikket og EU kunne være en kilde til økonomisk hjælp. Transnistriens 'præsident', Shevchuk, har sagt, at 30 pct. af Transnistriens eksport går til EU.

Men et øget økonomisk samarbejde med EU kræver en politisk kovending. I øjeblikket kræver EU ikke told på varer fra regionen, men den aftale udløber i januar 2016. Medmindre Transnistrien tilslutter sig den nye frihandelsaftale som Moldova har indgået med EU, vil Transnistriens eksport af tekstiler, stål og andre varer til EU blive meget hårdt ramt. $\mathrm{Og}$ der er en del forretningsfolk fra området, som er meget interesserede $i$ at samarbejde med EU, men som ikke tør sige det åbent.

Moldovas fremtid hænger i en tyndt tråd. Fra et vestligt perspektiv ville en russisk løsning være en tragedie af både strategiske og humanitære grunde. Alt tyder på, at de europæiske ledere tager Moldovas situation meget alvorligt. 